\title{
CATCHMENT AREAS AND UNIVERSITY GOVERNANCE IN NIGERIA: IMPLICATIONS FOR DEVELOPMENT
}

\author{
I.B. Bello-Imam and F.O. Nyemutu Roberts \\ Nigerian Institute of Social and Economic Research (NISER) Ibadan, \\ Nigeria
}

\begin{abstract}
Nigerian universities and other tertiary institutions are expected to play a pivotal role in the development of education in the country, and ultimately in national development. Recently the universities have been beset by a plethora of problems, one of which is the apparently simple but pernicious question of whether staff and students should be recruited on the basis of hiring quotas or by merit. Attempts to resolve the question has had dire implications for university governance and for the mission of the universities in national development. This is readily evident in the deployment of the concept of 'catchment areas', which pits ideas of equity in the plural society against those of efficiency and effectiveness.

This study explores the problems associated with the emphasis on 'catchment areas' in the management of recruitment into Nigerian universities. The analysis points to the significant influence of factors external to the university system over its internal dynamics, with significant consequences for educational and national development.
\end{abstract}

\section{Introduction}

When Nigeria attained political independence in 1960, there were high hopes of its potential for meaningful development. The hopes were based on its substantial natural resource endowment, the existence of a competent civil service, favorable economic growth rates, and above all, one of Africa's most developed university system. Today, the expectations have not materialised. The early gains in development of the educational sector have not been sustained, while grave doubts surround the anticipated role of the universities in national development. The expectations have been lost on the alter of national economic difficulties and, especially, political debacle.

The specific problems that constitute the university 'crisis' in Nigeria are many. By 1979, these included inadequacy of facilities, lack of funds, poor conditions of service, erosion of university autonomy, and mass exodus of academic staff from the universities especially abroad which phenomenon became known as 
the brain drain. In 1995, these problems have not only persisted, but worsened. Other problems also came to the fore during the intervening years. These include frequent strikes by academic and non-academic staff unions respectively, secret cults and incessant campus violence amongst student groups, frequent closure of the universities, vast politicisation of higher education, and the crisis of relevance foisted on the universities by both the national and the university leadership.

Most of the problems of Nigerian universities had their roots in the inability of Nigerian planners to resolve early enough the conflict underlining the true objective of educational development (F.R.N. 1970). This conflict between education as a consumer good and as a capital good was eventually resolved in favour of the latter. More than this, however, there have been difficulties regarding the proper conception of the purpose of universities in Nigeria, which has been handicapped by two factors, namely, the colonial heritage and the prevailing cultural traditions (ASUU 1987). The stubborn persistence of these handicaps consistently contradicts 'university culture'. Many commissions of inquiry have investigated and reported on the university crisis, yet the problems persist. In particular, the issue of politicisation of various aspects of university life, deriving from considerations outside the university system is of current concern in Nigeria

\section{Political Pluralism and Educational Imbalance}

Nigeria provides a good example of the classic plural society. With over 250 distinct ethnic groups spread over its 923,768 square kilometers, the country ranks seventh with 13 per cent homogeneity in terms of ethnic and linguistic homogeneity on an ascending scale in which North and South Korea are ranked 135th with 100 per cent homogeneity. This is compounded by a teeming population of about 88.5 million (by the 1991 Census) which makes the country nearly twice the size of any other African country. Nigeria is, therefore, built on a foundation for which astute ethnic arithmetic is necessary for its governance (Roberts 1994).

In 1995, the Federal Republic of Nigeria was made up of a Federal or Central government, 30 States, 589 local councils and a mayoralty in the Federal Capital Territory of Abuja. Although private universities are possible in principle, only the Federal and State governments as yet have the power to establish universities. The present political structure evolved from the adoption of federalism in 1954 which was initially based on three regions: North, East and West. Although the federal structure was originally adopted in response to an existing reality, namely, the geography of the major ethnic groups in the country it effectively regionalised Nigerian society and politics, and imbued Nigerians with an ethnic constituency mentality which currently pervades the educational sector. The federal system adopted in 1954 was, therefore, structurally flawed ab initio. Of particular significance was imbalance in the composition of the regions, with the Nm Hum Region 
dominating the rest both in geographical size (75 per cent of Nigeria's land mass) and population (60 per cent), but lagging behind in educational development. The structural defects promoted a structure of politics based on psychological fears of ethnic domination (Roberts 1994; Nnoli 1978).

In the educational sector, the regional imbalance is real. When Nigeria attained political independence in 1960 and the University of Ibadan (UI) was the only university with spaces for just 300 students, for every 1000 students registered, only 57 were from the north. This structure of imbalance has continued. In the 1992/93 academic session, Jigawa and Yobe states (north) recorded 0.46 and 0.40 per cent respectively for all university admissions, compared with 8.43 per cent for Imo (east), 7.77 per cent and 7.04 per cent respectively for Delta and Edo (midwest) (Adeniyi and Oni 1987; The Guardian, Lagos. 6 July. 1994:4).

It has been suggested that the observable regional imbalance in higher education in Nigeria has its foundations in non-educational factors that have structured the historical development of Nigeria, especially the pattern of the past differential responses to alternative avenues to mobility among which education was one. There was an initial lack of enthusiasm in the north because of the prior existence of the Islamic system of education (Adeniyi and Oni 1987). Federal authorities see the endurance of the educational imbalance as a 'recipe for instability'. Over the years, measures were therefore adopted to reduce the 'disparities'.

One of the measures adopted was the identification of the so-called Educationally Less Developed States (ELDS) for special attention. Most of the stales are in the north. Another measure adopted to correct the inter-state imbalance was the allocation of explicit quotas to the states. This is popularly known as the "federal character" of Nigeria's national institutions. Beyond the need to achieve political stability, the implementation of the federal character principle in the educational sector was officially predicated on considerations of justice and equity which, the government reasoned, demanded equalisation' of opportunities tor Nigerian children (F.R.N. 1975:244; 1981:8, para 6).

The implementation of the above measures fuelled the vast politicisation of higher education in Nigeria. With this came increasing demand for and the eventual proliferation of universities in the country, among other things, because the locality within which a university was sited necessarily reaped certain advantages. This fad of life was to be codified into a recruitment principle tor Nigerian universities as captured by the euphemism of 'catchment areas.

As a recruitment ideology, the invocation of 'catchment areas' (CA) seeks the reservation of certain rights and privileges for the benefit of individuals and groups within the locale of a federal or national institution or agency. In the universities, 
it is most readily associated with the preferential allocation of admission quota to 'indigenes' of the university location and its contiguous neighbourhood. This immediately compounds the very difficult problem of managing the social demand for access to higher education. However, as a factor in university governance, CA is also expressed in employment of staff, and key political and administrative appointments including the vice-chancellorship.

Among the factors defining the current university crisis, the CA phenomenon is important because of its subtle and pernicious expressions which tempt people to over look it. This perhaps underlines the relative absence of systematic efforts to analyze the problem of catchment areas in university governance in Nigeria.

\section{Affirmative Action, Equity and Justice}

The Nigerian literature lacks substantive works on the phenomenon (cf. Bello-Imam 1994; Adeyemi 1995). Adeniyi and Oni (1987:11) observe: "What is amazing is the apparently limited analytical input of Social Sciences into the problems and consequences of inequality in educational development and/or the instruments fashioned by government to deal with the problem".

The limited concern for the problems of regional educational imbalance and related issues is all the more disturbing because there are known concerns at the global level for better university governance which embrace issues such as the role of existing structures in constraining university responsiveness both to its internal constituencies and to national development objectives (Verspoor 1991; Saint 1992). Hon-Chan( 1971) also suggests that, in a plural society, political considerations might be accorded priority in certain circumstances in university governance. This might be especially so in the context of growing concerns for democratization of education in the form of measures to reduce specific inequalities (Carron and Chasu 1981). A much more embracing contribution to addressing these concerns is the discourse on affirmative action.

Studies (Glazer 1975; Goldman 1979) and contemporary dictionaries of politics (Bogdanor 1991; Robertson 1985; Scruton 1982) explain "affirmative action" both as policy and theory. As public or private sector policy, affirmative action refers to a deliberate policy designed to give preferential treatment to some groups in society on the grounds that they have hitherto been disadvantaged either by government policy or popular prejudice. Target groups often include ethnic minorities and women. Many democracies have adopted affirmative action, but its foremost translation into public policy is in the United States where the executive has been known to encourage the hiring and advancement of minorities by requiring, inter alia, that all organisations which have contracts with the federal 
government employ a given percentage of people of minority stock.

As political theory, the theory of affirmative action is sometimes referred to as the theory of reverse discrimination. It denotes such actions that are designed to advance, rather than merely conform to, the political vision underlying a doctrine of legal rights. If, for instance, it is determined that in tertiary education, identified educationally disadvantaged groups and women should be given the same rights as their advantaged and male counterparts, then affirmative action on the part of the appropriate educational authorities demands more than merely conforming to the code by giving equal consideration to all candidates. Such authorities are, in fact, expected to actively seek applications from the disadvantaged groups and so 'affirm' the underlying political vision which, if merely conformed to might result in the perpetuation of existing inequalities. Affirmative action is, thus, theoretically distinguishable from a system of 'quotas' which merely requires a particular outcome rather than a particular effort (Scruton 1982: 7-8).

Affirmative action is supposed to enhance the interest of the state in promoting minority progress, enhance justice through compensating minority groups that have suffered discrimination, and correct the failure of neutral criteria to achieve minority representation in sundry public institutions. It thus has defenders who see it as a necessary part of enforcing just distribution. On the other hand, affirmative action as reverse discrimination, is criticised for foisting injustice on individuals who might not necessarily have discriminated against minorities, and therefore, constitutes 'unjust discrimination'. Moreover, by dispensing public goods on the basis of sub-national values such as ethnicity, it encourages divisiness in the polity (Bogdanor 1991; Scruton 1982).

The theoretical and practical conception of affirmative action has remained ambiguous in part because its legal standards are rather vague. Thus, even in the United States, the policy remains a subject of considerable debate with regard to equity and justice.

Equity is an' interstitial' concept which argues that equals be treated equally and unequal's unequally. When the principle is taken to include within itself the conditions that determine what makes people equal or unequal, all other comparative distributive principles get subsumed in it. Conventionally, however, 'equity' takes the general outline of the distributive principle as given, and so calls attention to 'anomalies', 'inconsistencies' and 'incoherence'. One limitation of the conventional vision of equity is that it, for instance, allows for the possibility of the criticism of a set of policies as inconsistent without in depth assessment of the possibility that something might be wrong with the general principle or laws informing the policies. All that needs be done is to insist that what needs be done be done equally to all who are alike in relevant respects (Barry 1965) 
In many developing societies, equity seems to be seen primarily in terms of equal distribution', by which token, unequal distribution is inequity. To the extent that equity borders on justice, this ignores the fact that unequal distribution is some times more just than equal distribution (Goodwin 1987), as in the direction of the bulk of educational investments to so-called educationally disadvantaged areas There might then be something wrong in the equal treatment of the unequal, which suggests a conception of equity based on "carefully structured unequal treatment. devised so as to remove injustices and to compensate for natural disadvantages" (Goodwin 1987:299, original emphasis). This would seem to be the raison d'etre of affirmative action. However, even in the United States, a policy of affirmative action has proved very controversial to implement in the educational sector, especially in relation to university admissions (Robertson 1985). In developing countries such as Nigeria, the difficulties could be complicated by abuses of the policy.

\section{Catchment Areas and the Growth of Nigerian Universities}

Are staff and students of Nigerian universities to be recruited by merit or on the basis of hiring quotas? One response to this question has been the deployment of the phenomenon of 'catchment areas'. Catchment areas are the areas which people who are served by the university are primarily recruited. Also called 'locality ${ }^{5}$, in most cases this is the geographical or socio-cultural areas contiguous to the university. Official (government) directives regarding the implementation of CA mean giving more spaces to indigenes of the locality in which the university is sited. In retrospect, it has also ensured that students are not flung too far away from home especially in these days of escalating transport costs.

Officials of Nigeria's premier university, University of Ibadan, link catchment areas with the general scheme of distribution of spaces by quota to reflect the federal character (Interviews 2/3/95). As a concept, it therefore has diverse relations with ideas like "ethnic balance", "federal character", and "quota". While most of these ideas appear opposed to the merit criterion, emphasis on CA also tends to offend the desire to effectively reflect Nigeria's constitutional imperative by that name. This is more so because Nigeria's 1979 federal constitution forbids tribalism (F.R.N. 1979). Even so, CA remains a form of allotment of quotas for universities in Nigeria.

A system for placement by quota was conceived in Nigerian politics as a remedial measure in cases where public institutions especially Federal and State agencies, were perceived to have become monopolies of particular states or ethnic groups. Quotas emerged on the platter of fear of ethnic or sectional domination.

In the universities, a quota system of admission was introduced during the Second Republic (1979-83). As applied to federal universities, places were re 
served for indigenes of the constitutive states of the federation. This worked to the disadvantage of States from the South which produced many eligible candidates for enrolment but had only few places allocated to them. It was therefore widely perceived as a ploy to hold down the south for the less educationally developed north to "catch up". However, a former Education Minister from the north regards it as a "means by which you can increase the participation of all parts of the country" (Newswatch Lagos, 18/1/88). From the foregoing, CA would rank as a solution to the problem of imbalance in educational development, perhaps only with the proliferation of universities in the country, especially in the so called ELDS. Indeed, a favoured recipe nation-wide has been the establishment of more universities across the length and breadth of the country, with State universities emerging as the more beneficial to the cause of their indigenes. The obligation of each State university is primarily to the indigenes of the State funding it. Expectedly, those who benefit from the policy of catchment areas are reluctant to accommodate criticisms, let alone changes, to it.

The oldest Nigerian university, University of Ibadan, was established by the colonial government in 1948 as a University College. Since 1960, when the Ashby Commission urged that "highest priority" be given to university development, there has been a phenomenal growth in the number of universities. Between 1960 and 1972, there were six universities in Nigeria, located at Ibadan, Nsukka, Ile-Ife, Zaria, Lagos and Benin City. Between 1975 and 1976, a second generation of seven universities were established by the-Federal Government at Calabar, Port Harcourt, Kano, Maiduguri, Ilorin, Sokoto and Jos. Between 1980 and 1982. seven Federal Universities of Technology or Agriculture were established at Bauchi, Makurdi and Owerri (1980), Akure and Yola (1981) and Abeokuta and Minna (1982). Four of these were merged with older universities in 1984 for economic reasons only to be de-merged in 1987 for political reasons. Also in 1984, the Federal Government approved the establishment of a national university at Abuja.

Between 1979 and 1984, State universities were established in Rivers, Imo, Bendel, Anambra, Ogun and Lagos States. With the creation of more states in 1991, Imo State University became Abia State University, Uturu, while Bendel State University became Edo State University, Ekpoma. Since then, new State universities have been established in Delta, Enugu, Benue, Imo, Ondo and Oyo States. In 1991, the Federal Government took over the Cross River State University, Uyo and renamed it University of Uyo. A year later the (new) Anambra State University was similarly taken over and renamed Nnamdi Azikiwe University. In 1992, the Federal Government converted the School of Agriculture at Umudike, Abia State, into a University of Agriculture (JAMB 1994). Today there are 24 Federal Universities and 12 State Universities, plus one military university, 
the Nigerian Defense Academy (NDA), to make a total of 37.

One significant thing about the proliferation of universities in Nigeria is that it if mostly politically motivated and addressed to providing the benefits anticipated in the institution of the CA phenomenon.

\section{The Dilemma of Catchment Areas}

\section{Students Admission}

In recent years, there has been increasing concern over the modalities for admission of students into tertiary institutions of learning in Nigeria. In principle, candidates for admission into Nigerian universities have equal opportunities. In practice, extenuating variables mostly determined by politics prevail. For instance, to redress the problem of imbalance, the Federal Government adopted a policy of liberalising admission into universities by instituting remedial courses in selected universities especially to the advantage of the ELDS. While this policy largely achieved its aim, it had the weakness that it reduced the universities to playing the role of secondary schools in preparing students for universities. Secondly, because students then stay longer in the university, both the social and private costs of higher education are further increased.

The Federal Government also adopted a policy of centralising university admissions. Before $\mathrm{i} 978$, each university processed its own students admission. In that year, however the Joint Admissions and Matriculation Board (JAMB) was established by Decree (No. 2 of !978) to coordinate entrance examinations into Nigerian universities. JAMB was patterned after the Universities Central Council for Admission (UCCA) in England. However, whereas UCCA was created by that country's Council of ViceChancellors, JAMB was created by the Nigerian government.

The primary functions of JAMB are to determine matriculation requirements for Nigerian universities, conduct a joint matriculation examination for candidates seeking places in these institutions, and place suitably qualified ones. The centralisation of admission had the advantage that the student did not have to pay multiple examination fees for the various universities. The first Joint Matriculation Examination (JME) was conducted on April 29,1978 and candidates were placed in the then 13 universities, ostensibly based on their expressed preferences and level of performance.

In carrying out its statutory responsibilities, JAMB 'consults' and 'involves' the universities. This relation is guided by appropriate decrees and guidelines laid down both by the Federal and State Governments as the proprietors of the universities. For the federal universities, the Federal Government stipulates that a 
percentage of the candidates should be selected on merit, another percentage on locality. A proportion is reserved for candidates from the educationally less developed states and foreign students. The university is also allowed some discretion. This is in addition to the guideline that student admission should reflect a 40:60 Arts/Science ratio.

In preparing its brochure (first published in 1978) up to 1990, JAMB recognised the need to ensure that:

The peculiar admission requirements of each institution were retained. As these requirements were dictated largely by both tradition and the peculiar needs of each university's socio-political environment, it was considered important to allow the universities to retain their uniqueness (JAMB 1994:V). Presently, the guidelines for admission allocate 40 per cent to Merit; 30 per cent to Catchment Area/Locality; 20 per cent to Educationally Less Developed States, ELDS; and 10 per cent to University Discretion. The discretionary list comes from the Vice-Chancellor who is essentially the Chief Admission Officer of the university. From the percentage distribution, it is evident that 'catchment areas' is a very important principle in students admission, being often elevated above merit, in practice. The Admissions Officer of University of Ibadan admits that: "The order (to apply CA) is from the Federal Ministry of Education, and all universities are bound to obey" (Interviews 21/3/95).

The implementation of 'catchment areas' as a principle for students admissions has been associated with many problems, not least resentment from non-indigenes who suffer its consequence. We use the case of the massive admission scandal of University of Jos in 1992/93 to illustrate this. This was the case of a crisis of over-admission which was such that the university exceeded its admission quota by an alarming 5,075 students. The university's Branch of the Academic Staff Union of Universities (ASUU) went on strike in April 1993 to protest the "fraudulent' admissions procedure.

In the 1992/93 admissions at Jos, the University's discretionary list was effectively converted into a 'catchment' list, and this expanded it from 10 to 80 per cent. More than this, the place of CA in the crisis was also reflected in the 'faulty admission procedure' from the remedial class to the mainstream degree programme. A female student of the university captures it all:

This year alone, a total of 1,500 students have been admitted for remedial programme, and 500 would be eventually considered for degree programme. Fifty per cent of the 500 goes to the catchment areas of Plateau, Benue and Bauchi. The other fifty per cent would be shared by the rest 27 states and Abuja. Incidentally, 87.5 per cent of these candidates are from the non-catchment 27 states, just 12.5 per cent is sourced in the catchment 
areas. But in a situation where only 12.5 per cent of the students are from the catchment areas, would you not say all of them would gain entry into degree programmes, and at the expense of, probably, the more qualified candidates from the south. I am a victim of such circumstance, and that was why I had to battle my way in (Akanni 1994).

While CA is resented by disadvantaged non-indigenes, indigenes of the locality are staunch in its defence, its advantage in a federal university being surpassed only by the establishment of a state university which is not pretentious about its primary responsibility to local students. When, therefore, the Federal Government in 1991 decided to scrap die University of Cross River State, Uyo, the opposition to the decision by the indigenes was overwhelming. Not even the promise of a Federal University of Technology instead placated the people. The issue was more than substituting one university with another. The one was a State university and the other federal. The rules governing students and staff recruitment were different, if only in practice, being more favourable to the indigenes in a State university than in federal one where children of the locality would contend with the quota system. Also, there was the threat to the institution's remedial programme which had opened up possibilities for many indigenes who might not have had the benefit of university education. As in Jos, the benefit was reaped mainly by the catchment areas of the host states (Akwa-Ibom, Gross River State). as well as the neighbouring states. It is known that about 60 per cent of students admitted into the university came in through the remedial programme (Nyong 1991). Here is an exception to the conventional expectation in Nigeria that federal takeover of a State project is mostly welcome to host communities since this is conceived as increasing their share of the 'national cake'.

The only exceptions to the implementation of the CA rule are University of Ibadan for its premier status, University of Abuja for its 'national' status and the two universities of agriculture for their specialised status. Yet, even in the University of Ibadan, an official acknowledged subtle deference to "ELDS policy to capture the catchment areas".

\section{Staff Appointments}

The official policy of the Nigerian government on staff recruitment into universities merely deals with a unified salary structure. The universities articulate their own criteria for recruitment provided they respect the government laid-down staff-student ratio. The staff cadre also has to reflect the specific order of Professor ( 20 per cent), Senior Lecturer ( 25 per cent), and Lecturer (55 per cent). It is also a policy of government to allow for certain categories of administrative and supportive staff based on student enrolment and academic staff strength. 
Officials of the University of Ibadan (U.I.) deny that 'catchment area' plays a role in their staff recruitment. It is argued, for instance, that the university does not operate any specific recruitment policy for academic staff based on locality but aims to catch the best available in the national and international market. However, the reality of 'catchment areas' in staff recruitment into higher institutions of learning in Nigeria underlines the frequent furore over the actual states of origin of principal officers in these institutions, as was the case at the Federal Polytechnic, Ado-Ekiti, in 1988.

Considerations of CA have also played a role in the appointment of senior academic staff. Ideally, ethnic considerations should be of little significance in academic appointments. However, it is reported that at the University of Abuja, lecturers from outside the northern zone were considered as a 'threat'. In most cases, when they were given appointment at all, they were placed on part-time (Suleiman 1995). Similar reports had also been acknowledged with respect to other 'northern' universities which recruited expatriates, largely Asians, (in preference to Nigerians from the south), who might be placed on contract when necessity forced their recruitment. However, CA was not always to blame for such situations as in the University of Maiduguri where Nigerians from other parts of the country were reluctant to take up appointment, in part, because of the city's 'inclement' weather.

One area where 'catchment areas' is being indisputably invoked and which has often created a lot of friction in university governance is the selection and appointment of university leadership. Leadership in Nigerian university is patterned on the British model under which the university is governed by a governing council and a senate, while the Vice-Chancellor is both the academic head and the chief executive. Under the system, the principal leadership positions are those of the Vice-Chancellor, Deputy Vice-Chancellor (Administration), Deputy Vice-Chancellor (Academic), Registrar, Bursar, and Librarian.

Under normal circumstances, the Vice-chancellor is appointed by Gov-ern-ment after a process of selection by a Joint Committee of Senate, Congregation and Council. The candidate has to be acceptable to the university and the government. The Deputy Vice-Chancellors are elected from a group of professors identified and nominated by the Vice-chancellor. Those who win the election on the floor of the Senate are then appointed by Council for a period of two years. The Registrar, Bursar and Librarian are appointed by the University Council through a nation-wide advertisement, short-listing of applications and interview. When these officers, especially the Vice-Chancellor, are not properly appointed, governance is affected.

The vice-chancellorship of a Nigerian University is mainly an administrative 
position. Despite occasional controversies however, the post was until recently largely the preserve of professors. This underlines, ab initio, the significance of merit in the appointment. At Ahmadu Bello University, Zaria, where this norm was apparently flouted in the 1980s, it resulted in incessant crises which ultimately attracted a visitation panel. In 1995, Ahmadu Bello University again blazed the trail, when the Federal Government appointed a retired major-general as Sole Administrator of the institution in place of a vice-chancellor. This was the first instance when a non-academician would head a Nigerian university.

In recent years, it has become increasingly clear that those who head Nigerian universities are usually indigenes of the state or ethnic community in which the institution is located. At the University of Ibadan where officials deny any influence based on locality, all the principal leadership positions are currently (1995) being held by indigenes of the Yoruba tribe on whose soil the university is located. Only the Librarian, born Yoruba, can lay a technical claim of being an indigene of another 'area' (Rivers State) by marriage.

Where a non-indigene qualified for the headship of a university by merit, the process of leadership succession has more often than not been bogged with inconclusiveness. By April 1995, the University of Lagos sought the resolution of the crisis of the appointment of its Vice-Chancellor in the law courts amidst allegations of tribalism. At the University of Port Harcourt, there was mounting pressure (February 1995) to the effect that only an indigene of Rivers State where the University is sited be appointed the Vice-Chancellor.

A most pronounced expression of the politicisation of the appointment of ViceChancellors is the case of University of Jos (1993/94). Here, the Federal Government nullified the University Governing Council's choice on the ground that the Council had no voting power concerning the selection of Vice-Chancellors. Instructively, Chapter 5 of the September 3, 1992 Agreement between the Federal Government and ASUU, the National Universities Commission's letter to the Visitors of State universities, as well as the Universities (Miscellaneous Provision) Decree 11 of 1993, all vested the power to appoint Vice-Chancellors in the University Governing Council.

In the long-drawn struggle between ASUU and the Government in 1992 (Gana 1993), the government had conceded the 'determining role' in the appointment of ViceChancellors to the Councils. In contrast to earlier practice of sending three names from which the Visitor selected one, the Council was empowered to select one of the three names submitted to it by the Joint Council-Senate Committee and forward the same to the Visitor for approval. This had the advantages that, first, it freed the Visitor from the multiple pressures mounted by (he three short-listed candidates, and second, forced aspirants to look inward to their 
constituency, the university, rather than to the Visitor and his cohorts for support. However, the provision that the Visitor could reject the name sent by the Council left a wide room for manoeuvre. It was this provision the government exploited in subverting the popular will of the university in Jos, and elsewhere in Minna.

In reality, the true reasons for the rejection of Council's choice at Jos were known to be the supposed 'uncompromising' stand of the candidate concerned on national issues, and more importantly, that he was not a Plateau State indigene, but an indigene of Niger State. The significance of catchment areas' in this case was evident from the fact that the Federal Government rather appointed an indigene of Plateau State who had scored only two of the ten votes cast whereas the Council's candidate scored seven. In Jos, as in Minna, the Federal Government went ahead to appoint Vice-Chancellors against the recommendations of the Governing Council.

The politicisation of staff recruitment into Nigerian universities has been such that even campus gangs are known to affect appointments. A Gamji Society at Ahmadu Bello University. Zaria, was reported to have "not only sponsored a Vice-Chancellor candidate but threatened to let loose all the dogs of hell if he was not appointed" (Soyinka 1994.). As early as 1965, there was a clash between student supporters of two candidates for the Vice-Chancellorship of University of Lagos.

It is evident that the phenomenon of 'Catchment Areas' remains an enduring cankerworm of a policy, the implementation of which is subject to many interpretations by the implementers. It also remains part of the 'destructive virus of localization' which stares Nigerian universities in the face today. And as Gana (1993) notes in respect of the theatrics of the appointment of Vice-Chancellors of Jos and Minna, few institutions in Nigeria seem to have risen beyond this 'calculus of political brinkmanship'.

\section{Implications for Development}

The pursuit of a policy of 'Catchment Areas' has dire implications both for the development of education in the universities and for the contribution of the universities to national development. By implication, the application of 'Catchment Areas' in university recruitment could immediately compromise standards, quality of scholarship and studentship, and general educational development. One plausible effect of application of 'Catchment Areas' to admission, in particular, appears to be the fall in the standard of education.

There are opinions to the effect that there is no scientific basis behind the claim that the standard of education has fallen in Nigeria. This is supported by the difficulty in quantifying the quality of education, a task made even more difficult by lack of data such that it has been easier to examine inputs, books and teachers, as a gauge (Anyadike 1988). 
In the absence of statistics, 'circumstantial evidence' as to the fall in standards in Nigerian universities is provided by professional regulatory bodies, the Council of Registered Engineers which registers engineers, the Medical Council which registers doctors and the Council for Legal Education which oversees the training of lawyers. To take only the example of lawyers, there was 'mass failure' at the Nigerian Law School in 1987. This could have been due to a variety of factors of which 'Catchment Areas' is only one. The implication of the phenomenon and related issues was quite evident in the observation of the Secretary of the Council of Legal Education on the issue:

Merit should be the only yardstick and the current practice whereby students who do poorly but are pushed to the Law School because they come from educationally disadvantaged areas will only help to speed the decline in the standard of education (Newswatch Lag6s, 18/1/88:14).

The implementation of the 'Catchment Areas' principle in student's admissions also robs candidates who scored higher marks than their counterparts from the catchment area of the opportunity to be admitted to the course of their choice. Furthermore, because mediocrity enthroned by the phenomenon can hardly stand brilliant academics, frictions emerge which contribute to destablishing the universities and reinforce the decline of standards. More importantly, prima facie qualified students unable to secure admissions have been forced into illegalities to secure placement which underlines the prominence of 'fake students' in some Nigerian universities. The foregoing once again highlights widespread perceptions of injustice and inequities - the very issues CA was supposed to address.

Relative to staff recruitment, the implications are no less daunting. When 'sons of the soil' head universities^ the tendency is for them to employ mainly their kinsmen whether they be suitably qualified or not, and this also enthrones mediocrity. When this is the case, the morale of those recruited on merit is lowered by the filling of their ranks with catchment-area recruits. This has sometimes been associated with non-commitment of staff to duty in the tertiary institutions which denies the institutions commensurate output considering the overhead costs incurred.

In the specific case of appointment of Vice-Chancellors, the external imposition of candidates on the universities has divisive effects which contribute to instability in the system. This is inimical to the necessary atmosphere for conducive learning. Resultant prolonged leadership vacuum, where this occurred, has been injurious to the interest of the university by hampering academic work and other programmes of the institutions. The influence of 'catchment areas' in Vice-Chancellors appointments also imposes hamstrings on university autonomy, 
especially in the involvement of academics in the democratic administration of their schools. Injustice becomes a directive principle of university governance, while the system's inequities become multifaceted and intriguingly compounded. Above all, the localisation virus elevates ethnicity over and above academic merit and underlines the emergence, therefore, of ethnicity as a weapon in the hands of the Nigerian ruling class with real potentials for the destruction of universities. In Jos, where the Federal Government clearly yielded to pressures from "some eminent Nigerians who wanted an indigene of Plateau State as the Vice-Chancellor" (The Guardian Lagos, 19/4/94:36), the rejection of the Council's nominee dampened the morale of the numbers.

In general, the implications 01 catchment areas' for university development and governance are ominous. Its implementation creates power blocs which multiply dialogues at both formal and informal levels. The university administrator becomes confused by the necessity to balance rival claims. 'Catchment Areas' also tends to exacerbate ethnic tensions by giving to one or more ethnic groups economic and political advantages which others regard as unfair and, therefore, unjust. Overzealous administrators have capitalised on the 'bad situation' to pursue their parochial interests. The failure of administrators of some of the universities to recongnise or even acknowledge what is apparent underlines the very rea.1 danger that Nigerian universities might be breeding 'tribal intellectuals'.

Again, the routine squabbles generated, together with other facets of the university crisis, threaten the image of the university as a citadel of learning. As ASUU observed in relation to the admissions crisis at Jos, the situation was capable of damaging the professional integrity of lecturers, and defeating the university's ideals and the very purpose of university education. Nothing destroys a system faster than a policy of appeasement towards any part of the system which is perceived as trampling on the rights and sanctity of the rest. Hence, the negative implications of 'Catchment Areas' for the ability of the system to pursue the acknowledged goals of the university which include: (i) transformation of the university into a legitimate national institution for higher learning; (ii) production of skilled human resources necessary to manage (relatively) newly independent countries; (iii) generation of developmentally relevant research; (iv) provision of community service; and (v) constitution of a diverse and representative student body (Saint 1992).

Today, Nigerian universities are a poor symbol of the intrinsic relationship between education and development. Nationwide, the universities are failing to make the right impressions on national development as deteriorating conditions make them unsuitable for such task. This underlines current concerns for the relevance of the universities to national needs which, for both government and 


\section{Annals of the Social Science Council of Nigeria, No. 9, January-December, 1997}

citizens, relate to variables such as choices within and outside the universities that are germane to the national economy.

\section{Conclusions}

The phenomenon of 'Catchment Areas' is one of the political mechanisms devised for managing the plural society in Nigeria. With theoretical basis in the theory of affirmative action, its specific application to the educational sector alongside the quota system as a solution to the problem of regional educational imbalance has, however, yielded a plethora of unintended problems which demonstrate the far-reaching effect of factors external to the university system on the internal dynamism of the system. The banal struggle for territorial hegemony reflected in the policy of 'Catchment Areas' reflects a certain over-politicisation of university education which has tended to undermine university governance, educational development in the universities, and ultimately the contribution of the universities to national development.

Given the existence of a systematic relationship between the university system and forces in the political system, the university administrator who fails to consider carefully the underlying social and politically underscored tensions in university governance, including the incidence of 'Catchment Areas', risks inadvertently exacerbating the tensions and further undermining the noble mission of the university. This intricate relationship reinforces the recognised need for the political scientist to come as systematically into educational planning as economists did decades ago.

It remains to observe that balancing the contradictions in the educational system demands a range of instruments wider than the conventional array of administrative tools and planning techniques currently in use. This recommends hard rethinking on the politics of education in developing countries, particularly the need to depoliticize the system through the creation of a liberating cultural and educational policy which should allow universities to develop based on their individual and collective perception of the needs of the society, available staff and facilities. Under such scheme, recruitment will be based on need rather than on a stereotyped government policy.

\section{References}

Adeniyi, E.O. and B. Oni (1987) "Regional Equity and Higher Education in Nigeria: Dilemma", Paper presented at the Fourth General Assembly of the Social Science Council of Nigeria, Ahmadu Bello University, Zaria, June 1-3.

Adeyemi. K. (1995) "The Catchment Area Factor in University Admissions in Nigeria". On-going research billed for submission to the Social Science 
Catchment Areas and University Governance, in Nigeria: Implications for Dev.

Council of Nigeria (April/May).

Akanni, T. (1994) "When the Fleece is not Golden" The Guardian on Sunday; Lagos, June 12, p. Bl.

Anyadike, O. (1988) "The Education Crisis", West Africa. September 5-11, pp. 16221624. ASUU (1987) ASUU and the 1986 Education Crisis in Nigeria, Ibadan ASUU (National Secretariat).

Barry, B. (1965) Political Argument, London: Routledge and Kegan Paul.

Bello-Imam, I.B. ed. (1994) University Governance in Nigeria, Proceedings of the Eight General Assembly of the Social Science Council of Nigeria, Ibadan, SSCN.

Bogdanor, V. ed. (1991) The Blackwell Encyclopedia of Political Science, Oxford: Blackwell Publishers.

Carron, G and Ta Ngoc Chau (1981) Reduction of Regional Disparities: The Role of Educational Planning, Paris: International Institute for Educational Planning.

F.R.N. (1970) Second National Development Plan, 1970-74, Lagos: Federal Ministry of Information.

- (1975) Third National Development,Plan, 1975-1980, Lagos: Federal Ministry of Economic Development.

- (1979) Constitution of the Federal Republic ofNigeria 1979. Lagos: Department of Information.

----- (1981) National Policy on Education, (Revised), Lagos: NERC Press.

Gana, A.T. (1993) "The Nigerian University at the Crossroad", Annals of the Social Science Council of Nigeria, 5,pp. 1-15.

Glazer, N. (1975) Affirmative Discrimination: Ethnic Inequality and Public Policy, New York: Basic Books.

Goldman, A.H. (1979) Justice and Reverse Discrimination, Princeton, NJ: Princeton UP.

Goodwin, B. (1987) Using Political Ideas, Second edn., Chichester: John Wiley and Sons. 
74 Annals of the Social Science Council of Nigeria, No. 9, January-December, 1997

Hon Chan, Chai (1971) Planning Education for a Plural Society. Paris: UNESCO.

JAMB (1994) Guidelines for Admission to First Degree Courses in Nigerian

Universities, 1994/95 Session, Lagos: Joint Admission and Matriculation Board.

Nnoli, O. (1978) Ethnic Politics in Nigeria, Enugu: Fourth Dimension Publishing Co. Ltd.

Nyong, F. (1991) "Rumpus Over UNICROSS", The Guardian on Sunday, Lagos, September 29, p. A7

Roberts, F.ON. (1994) "Local Government, Participation and Development in Nigeria", Unpublished Ph.D. Thesis, University of Birmingham, United Kingdom.

Robertson, D. (1985) The Penguim Dictionary of Politics, Penguin Books. Saint, W.S. (1992) Universities in Africa: Strategies for Stabilization and Re-vitalization, The World Bank.

Scruton, R. (1982) .4 Dictionary of Political Thought, London: Macmillan.

Soyinka, W. (1994) "Democracy and the University Idea; The Student Factor", The Guardian, Lagos, May 19 and 27.

Suleiman, M. (1995) "Abuja Varsity, Correct this Imbalance"' Daily Sketch, Ibadan. March 24, p. 2.

Verspoor, M. (1991) "Planning of Education: Where Do We Go?" Unpublished Mimeograph. 